\title{
CHANGES IN POLISH AGRICULTURE AFTER THE ACCESSION TO THE EUROPEAN UNION
}

Anetta Wasniewska ${ }^{1}$, dr inz.; Hanna Kruk ${ }^{2}$, dr

1,2 Gdynia Maritime University

\begin{abstract}
There have been many problems regarding Polish agriculture before the accession to the European Union. The following main weaknesses were identified: fragmentation of farms, the use of obsolete methods for cultivation and breeding, low profitability of agricultural holdings, lack of additional functions in rural areas (processing, tourism, other services), relatively high unemployment (registered and hidden) or environmental problems. Many financial instruments have been used since 2004, some of which are worth mentioning, namely: direct payments, structural benefits, promotional investment loans for farmers, agri-environment programme subsidies, funds provided under the rural development programme. The EU accession resulted in the changes to the countryside, including: enlargement of average farm area, higher average income for farmers, extension of the area under integrated farm management, increase in the number of organic farms or fixed assets in agriculture. The main goal of the paper is to analyse the changes in Polish agriculture after joining the EU (in general and for the regions). A database was generated in line with Polish Central Statistical Office (GUS) data. The correlation method and least squares method have been used in the course of the examination.
\end{abstract}

Key words: agriculture, Poland, regional differentiation, correlation method.

JEL code: 013, Q15, Q18, C54

\section{Introduction}

Till year 1989, Polish agriculture had been developing in conditions of non-market, centrally planned economy. In addition to private, family farms (comprising over $57 \%$ of arable land), there had also been state-owned farms and (as a small percentage) agricultural cooperatives (Gazinski B., 2006). The main problems of Polish agriculture in the period after economic transition and before accession to the European Union (EU) were following: land and agricultural holdings fragmentation, overpopulation of rural areas (large number of people at the countryside on 100 ha of cropland), high agricultural unemployment rate (overt and hidden), relatively high poverty, low level of education in comparison to inhabitants of urban areas ( Fedyszak-Radziejowska B., 2005; Gazinski B., 2006; Gorzelak E., 2010; Matyka M., 2014).

The main aim of changes made after the year 2004 included adaptation of Polish agriculture to the functioning under market economy conditions. After joining the EU, the principles of Common Agricultural Policy (CAP) were implemented into its Polish counterpart. CAP is based on two main areas: market and price policy as well as structural policy. CAP includes many instruments providing improvement of agriculture productivity, better welfare for farmers, assurance of food the availability, guaranteed food self-sufficiency and a stable situation at the agricultural market (Deluga W., 2014; Gorzelak E., 2010). The presumptions of the CAP have been modified: in 2003 it was assumed that the agriculture support should be provided to improve its competitiveness, while at the same time, setting the requirements of higher standard of living for farmers and better environmental state (Gorzelak E., 2010). For years 2014-2020 two main areas of CAP have been established: marked measures regulating and supporting agricultural market and direct payments ( $1^{\text {st }}$ fund) and rural development ( $2^{\text {nd }}$ fund) (Grzelak M.M., 2014, s. 111).

Agriculture is one of the main sectors in Poland, although its share in GDP has been continuously decreased (Concise Statistical Yearbook of Poland, 2017; Matyka M. 2014). Since Poland joined the EU, farmers have been receiving financial assistance, including direct payments (area payment, production quotas, payment for special crops and special support) and others like 
agri-environmental measures, LFA Payments (supporting farmers at less-favourable areas), promotional investment credits for agriculture, subsidies within the programme for agriculture development. Financial support has referred to selected activities as well, such as: structural pensions, the young farmer payment, afforestation, diversification payment, supporting semisubsistence farms or producer groups etc. The value of such financial assistance has been permanently increasing from year to year. It resulted in improved farmers' income (Gazinski B., 2006; Orlykovskyi M. and Wicki L., 2016; Subsidies versus economics..., 2016).

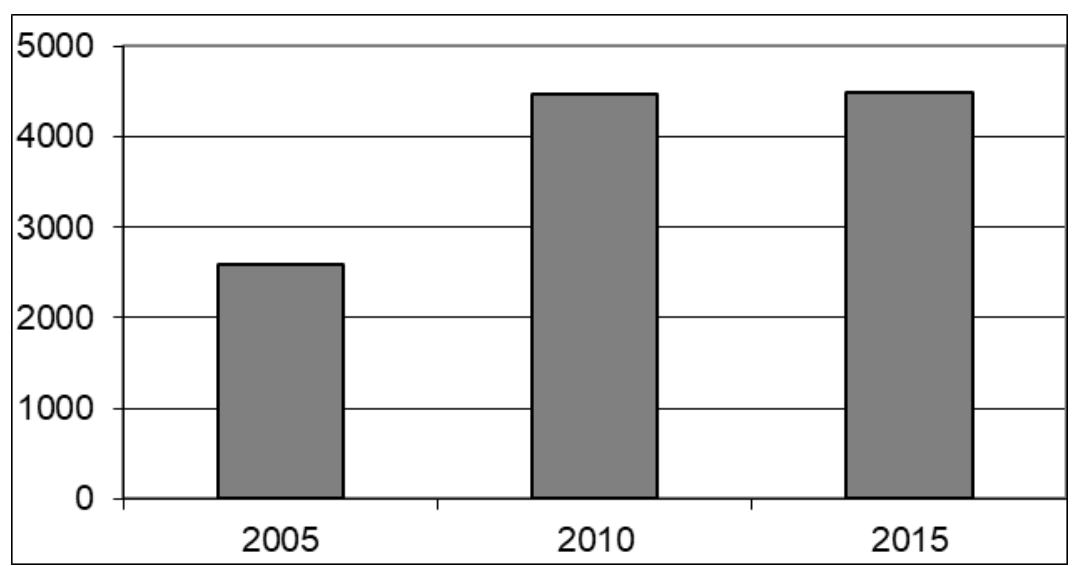

Source: Statistical Yearbook of Agriculture 2016, p. 224

Fig. 1. Average income of farmers per household (in PLN) - changes in years 2005-2015

Consequently, owing to the actions taken since 2004, the structure of agriculture holdings has improved: the total number of farms and the amount of the smallest ones (of agricultural area less than $5 \mathrm{ha}$ ) have fallen down, while the average area of holding has increased. The decline in cultivated land area has been also noticed, as a result of transferring land for non-agrarian purposes (Deluga W., 2014; Kopinski J., 2015; Mickiewicz B. et al., 2013; Wigier M., 2014). Moreover, agricultural producer groups have started to develop (Falkowski et al., 2017) so have certified, organic farms (Kus J., 2014; Markuszewska I. and Kubacka M., 2017). Fixed assets in agriculture (including buildings, machinery and technical equipment) improved as well (KarwatWozniak B., 2011).

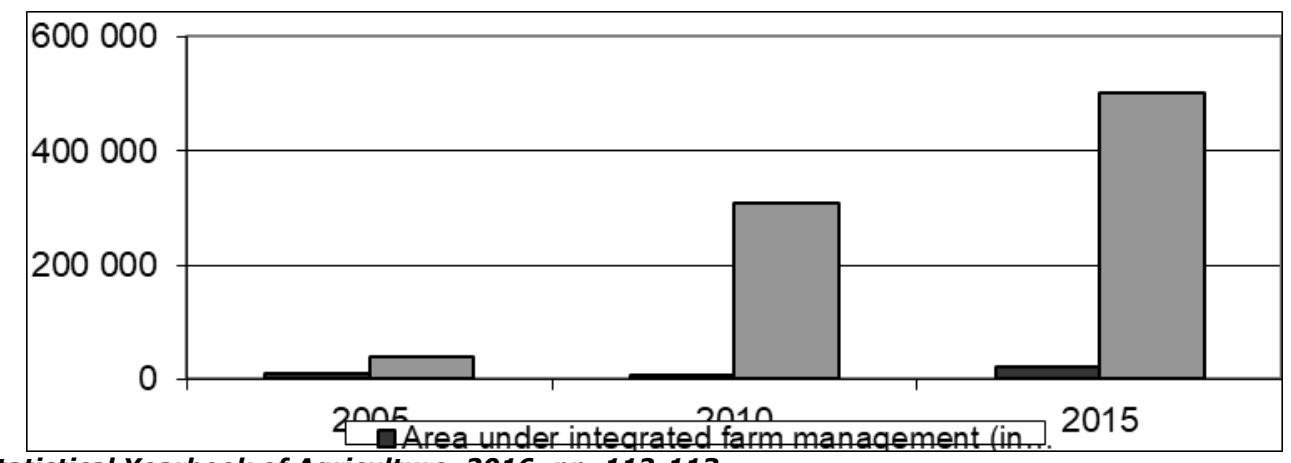

Source: Statistical Yearbook of Agriculture, 2016, pp. 112-113

Fig. 2. Area of farms in Poland under integrated management and certified organic farms changes in years 2005-2015

It is also worth mentioning that despite general situation of Polish agriculture have enhanced, its regional differentiation remains significant. It depends not only on regional specialisation and specificity but also on applied aid instruments and their efficiency (Kopinski J., 2015).

The aim of the paper is to analyse main directions of changes in Polish agriculture after the accession to the EU and the differences between regions (provinces). Previously published research results concerning alteration in agriculture have focused on the analysis of selected factors, and 
usually have considered the country level (Matyka M., 2014; Roman M. and Nuszkiewicz K., 2013). Quite rarely have the changes been examined at the regional level and, in general, only in case of a few, selected determinants, regarding agricultural productivity, changes in arable area, ecological farming or (more coprehensively) set of socio-economic factors (Karwat-Wozniak B. 2011; Kopinski J. 2015; Kus J., 2014; Mickiewicz B. et al., 2013). Novelty in the paper includes the use the least squares method and econometric model (based on 15 variables) to perform a complex analysis of the changes in Polish agriculture in years $2005-2015$.

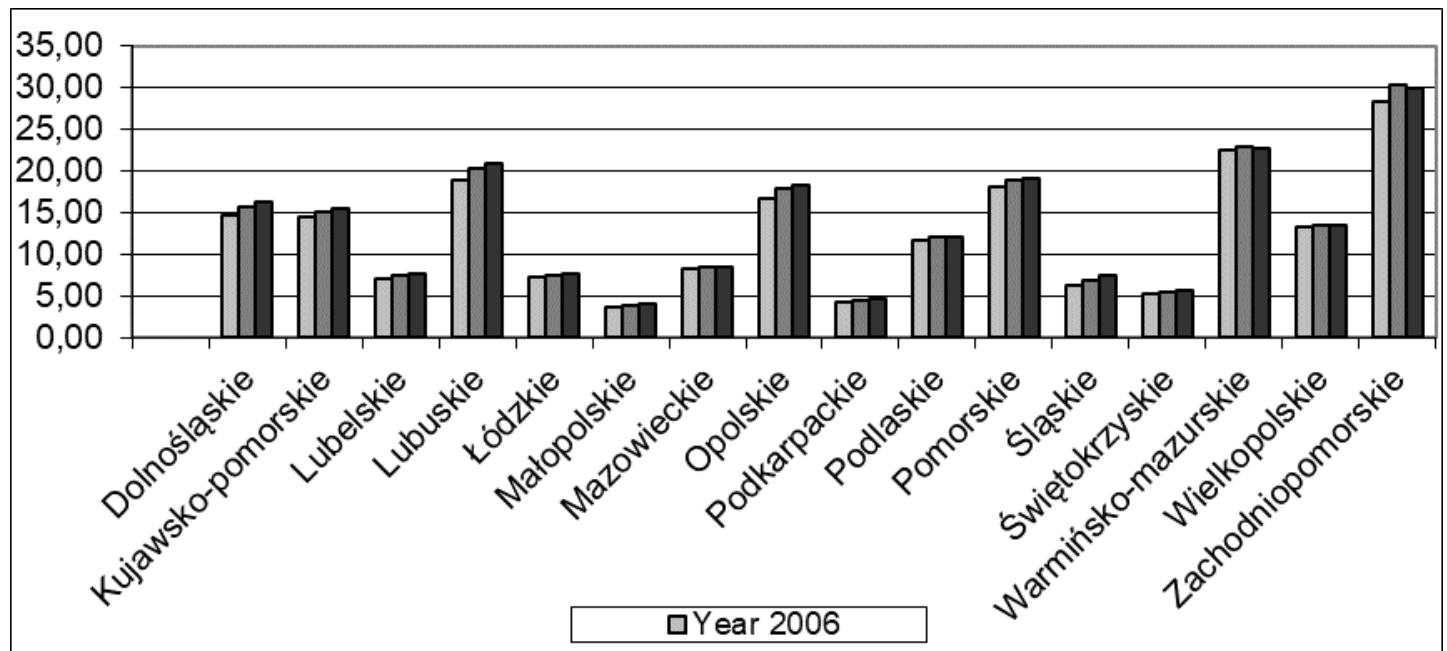

Source: Announcements of the president of The Agency for Restructuring and Modernisation of Agriculture http://www.arimr.gov.pl/pomoc-krajowa/srednia-powierzchnia-gospodarstwa.html

Fig. 3. Average arable area in farm (ha)

Analysis at the regional level would allow identification of regional disparities between the socioeconomic determinants of agricultural development, efficiency of the state policy and effectiveness of financial assistance in the regions.

\section{Research results and discussion}

To examine the changes that took place in Polish agriculture after joining the EU, the following data were used:

- publications of the Central Statistical Office in the Statistical Yearbooks of Agriculture;

- the communication materials made available by the Agency for Restructuring and Modernization of Agriculture.

The years 2005, 2010 and 2015 were selected for the analysis. The choice of these years was caused by the availability of data, and at the same time allows observation of phenomena occurring in agriculture in cyclic terms, which took place in the same five-year periods.

The analysis was based on data at the voivodship level (NUTS 2). There are 16 such areas in Poland. The largest voivodship in terms of size is the Mazowieckie Voivodship, which covers $35558 \mathrm{~km}^{2}$, while the smallest area has the Opolskie Voivodeship $\left(9412 \mathrm{~km}^{2}\right)$.

The most densely populated is the Silesian Voivodeship, where per $1 \mathrm{~km}^{2}$ there were 370 people in 2016, and the least populated were the Warmian-Masurian and Podlasie Voivodships, where only 59 people per $\mathrm{km}^{2}$ were occupied.

The largest share of agricultural land in percentage to the total area of the voivodship in 2016 was recorded in the Malopolskie Voivodship and amounted to $82.3 \%$, and the largest in the Opolskie Voivodship (95.75\%). 
For a detailed analysis of the situation of Polish agriculture after entering the EU structures in the analysed years, at the initial stage, 40 variables were identified that are observable at the NUTS 2 level in Poland. However, only 15 variables were analysed in detail, which were characterized by a coefficient of variation at the level of medium and high variation.

The average size of agricultural land on an agricultural holding was considered to be an endogenous variable. The choice of this variable was influenced by the critical analysis of publications (studies), whose authors emphasized its importance for the development of the situation in Polish agriculture after accession. Changes in the area of farms (increase in the average area of the farm, sale of unprofitable farms, purchase of land from the state, EU subsidies for young farmers, etc.) contributed to the increase of economic efficiency of agriculture in Poland.

For further analysis (on the basis of the coefficient of variation), exogenous variables were defined, which were included in Table 1.

Table 1

Exogenous variables

\begin{tabular}{|l|l|}
\hline \multicolumn{1}{|c|}{ No } & \multicolumn{1}{|c|}{ Question } \\
\hline $\mathbf{X 1}$ & Ecological farms with a certificate (pcs) \\
\hline $\mathbf{X 2}$ & The area of organic farms with a certificate (ha) \\
\hline $\mathbf{X 3}$ & Ecological farms in the waiting for the certificate period (pcs) \\
\hline $\mathbf{X 4}$ & The area of ecological farms in the waiting for the certificate period (ha) \\
\hline $\mathbf{X 5}$ & Cultivation area covered by integrated production methods (ha) \\
\hline $\mathbf{X 6}$ & The number of rural population (person) \\
\hline $\mathbf{X 7}$ & The number of rural population per 1 km ${ }^{2}$ \\
\hline $\mathbf{X 8}$ & The number of rural villages (pcs) \\
\hline $\mathbf{X 9}$ & The average number of rural population in one village \\
\hline $\mathbf{X 1 0}$ & The revenues to the budget of local government units of the agricultural tax (PLN) \\
\hline $\mathbf{X 1 1}$ & $\begin{array}{l}\text { The revenue to the budget of local government units due to the agricultural tax, including the } \\
\text { commune (PLN) }\end{array}$ \\
\hline $\mathbf{X 1 2}$ & Working in agriculture (person) \\
\hline $\mathbf{X 1 3}$ & The value of agricultural products purchased in 1 ha of agricultural land -total (PLN) \\
\hline $\mathbf{X 1 4}$ & The value of agricultural products purchased in 1 ha of agricultural land - plant products (PLN) \\
\hline $\mathbf{X 1 5}$ & The value of agricultural products purchased 1 ha of agricultural land - animal products (PLN) \\
\hline
\end{tabular}

Then, for each of the three analysed years, a vector and a matrix of correlation coefficients between variables was calculated. The highest positive values of the correlation coefficient between exogenous variables for 2005 were obtained in the case of the impact of variables: X10 X11; X13 $X 15$ and $X 7 X 9$. Whereas the highest negative values were obtained between variables $X 9 X 11 ; X 8$ $X 9$ and $X 1$ X13. Respectively, in 2010 the highest positive values were recorded for variables $X 10$ $X 11$ (the same relationship was visible in 2005); X7 X9 and $X 3 X 4$; respectively, the largest negative values occurred for variables $X 4 X 7 ; X 1 X 13$ (this relationship was also in 2005) and X8 X9. In contrast, in 2015 the highest positive values of correlations between variables were recorded in the case of $X 10 \times 11 ; X 2 X 4$ and $X 1 \times 3$. The highest negative values for this year were obtained for X2 X7; X4 X7 and X3 X7 (Cieslak, M. 2005).

At the next stage of the analysis, the significance level of the model $(v=0.1)$ and $n-2$ degrees of freedom were determined and the statistical values were read from the Student's t-charts. On this basis, the critical value of the correlation coefficient was determined $(r *=0.426)$. For each of the years the separation $(2005,2010,2015)$ from the set of potential explanatory variables were 
exogenous variables that were negligible correlated with the endogenous variable. In the next stage, the variable most strongly correlated with the endogenous variable was selected. Then, these exogenous variables are eliminated, which are too strongly correlated with each other, because they repeat the previously provided information to the model (Sobczyk M., 2013).

On the basis of this analysis, the variables that should be included in the models (Table 2 ) were defined.

Table 2

\section{Exogenous variables obtained by elimination}

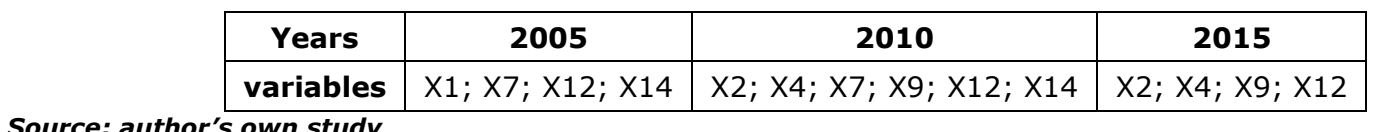

Then, using the classic method of least squares, the values of structural parameters of models for each of the analysed years were calculated. In order to check the significance of the parameters, the F-Snedecor test was additionally used. Non-significant parameters have been eliminated. As a result, the following models were presented.

$$
\begin{gathered}
Y^{\wedge}(2005)=0.005 X_{14}-0.133 X_{7}+22.557 \\
(+/-0.004)(+/-0.036)(+/-3.645)
\end{gathered}
$$

Interpretation 2005:

if the purchase value of agricultural products from 1 ha of agricultural land of plant products increases by PLN 1, the average size of agricultural land on the farm will increase by 0.005 ha, assuming that the number of rural population per $1 \mathrm{~km} 2$ will be at the same level.

If the number of rural population per $1 \mathrm{~km} 2$ decreases by 1 person, the average area of agricultural land on the farm will decrease by 0.132 ha, assuming that the value of purchase of agricultural products from 1 ha of agricultural land of plant products will remain at the same level.

$$
\begin{gathered}
Y^{\wedge}(2010)=0.005 X_{14}+16.828 \\
(+/-0.030) \quad(+/-3.968)
\end{gathered}
$$

Interpretation 2010:

If the value of purchase of agricultural products from 1 ha of agricultural land of plant products increases by PLN 1, the average size of agricultural land on the farm will increase by 0.005 ha.

$$
\begin{gathered}
Y^{\wedge}(2015)=-0.001 X_{12}+22.128 \\
(+/-0.001) \quad(+/-2.334)
\end{gathered}
$$

Interpretation 2015:

if the number of employed in agriculture decreases by one person, the average size of agricultural land on the farm will decrease by 0.001 ha.

It should be noted that in the analysed years 2005 and 2010, the average size of agricultural land in farms was affected by the value of purchase of agricultural products from 1 ha of agricultural land of plant products. In contrast, in 2005 and 2015 years are beginning to be noticeable demographic trends. The decline in the number of rural population and the lack of people employed in agriculture are becoming more and more important.

The model fit for 2005 was $78.21 \%$, for 2010 was $94.02 \%$, for 2015 was $87.80 \%$.

\section{Conclusions, proposals, recommendations}

- After Polish accession to the EU, the situation in the agriculture has significantly improved: the structure of crops and livestock breeding changed, the area under integrated farm management 
and number of certified organic farms increased. The average income from farm and revenue of local authorities on agricultural tax rose remarkably as well. The amount of farmers injured in accidents at work in agriculture diminished noticeably. Life expectancy of farmland inhabitants lengthened. Due to high investment spending, the fixed assets (buildings, machinery, technical and transport equipment) in agricultural holdings also improved.

- Despite the aforementioned changes, some problems have not been solved. There are still differences between Polish agriculture and the EU (especially comparing to Western European countries), particularly in case of land fragmentation in Poland (only the small improvement since 2004) and farmers' income. The small farms up to 10 ha of arable area still dominating in Poland (the smallest ones, with the area until 5 ha consisted approximately $60 \%$ of them). Significant problem is relatively high unemployment rate within rural areas.

\section{Bibliography}

1. Concise Statistical Yearbook of Poland (2017). Warszawa: Glowny Urzad Statystyczny, p. 395.

2. Cieslak, M. (2005). Prognozowanie gospodarcze. Metody i zastosowania. Warszawa: Wydawnictwo Naukowe PWN, pp. 139-148.

3. Deluga, W. (2014). Wybrane aspekty finansowania polskiego rolnictwa $w$ ramach wspolnej polityki rolnej Unii Europejskiej. Roczniki Naukowe Stowarzyszenia Ekonomistow Rolnictwa i Agrobiznesu, vol. 16, No. 6, pp. 101-104.

4. Falkowski J., Chlebicka A., Lopaciuk-Gonczaryk B. (2017). Social Relationships and Governing Collaborative Actions in Rural Areas: Some Evidence From Agricultural Producer Groups In Poland. Journal of Rural Studies, vol. 49, pp. 105-106.

5. Fedyszak-Radziejowska, B. (2005). Kilka slow o zalozeniach, realizacji i wynikachbadania procesu demarginalizacji polskiej wsi. Warszawa: Instytut Spraw Publicznych, Instytut Rozwoju Wsi i Rolnictwa PAN, pp. 1-2.

6. Gazinski, B. (2006). Polskie rolnictwo w Unii Europejskiej i niektore doswiadczenia pierwszego roku czlonkostwa. Biuletyn Instytutu Hodowli i Aklimatyzacji Roslin, No. 242, pp. 4-8.

7. Gorzelak, E. (2010). Polskie rolnictwo w XX wieku. Produkcja i ludnosc. Warszawa: Prace i Mateiraly Instytutu Rozwoju Gospodarczego SGH, pp. 21-24, 94, 100, 114-121, 183-187.

8. Grzelak, M.M. (2014). Szanse i zagrozenia rozwoju polskiego rolnictwa w nowej perspektywie finansowej UE na lata 2014-2020. Annales Universitatis Mariae Curie-Sklodowska, sectio H, vol. 46., No. 3, p. 111.

9. Karwat-Wozniak B. (2011). Regional differentiation in the socio-economic development conditions of the agriculture in Poland. Economics \& Sociology, vol. 4, No. 2, pp. 12-24.

10. Kopinski, J. (2015). Agri-environmental Effects Of Changes In Agricultural Production In Poland. Agrosrodowiskowe skutki zmian produkcji rolniczej w Polsce. Economic and Regional Studies. Studia Regionalne i Ekonomiczne, vol. 8, No. 3, pp. 7-17.

11. Kus J. (2014). Stan rolnictwa ekologicznego na swiecie w Unii Europejskiej i Polsce. In: Wybrane problemy rolnictwa polskiego z uwzglednieniem stanu jego zrownowazenia. Pulawy: Studia i Raporty IUNG-PIB, vol. 40(14), pp. 34-43.

12. Markuszewska I. Kubacka M. (2017). Does Organica Farming (OF) Work In Favour Of Protecting The Natural Environment? Case Study From Poland. Land Use Policy, vol. 67, pp. 499-500.

13. Matyka M. (2014). Stan rolnictwa w Polsce na tle Unii Europejskiej. In: Wybrane problemy rolnictwa polskiego z uwzglednieniem stanu jego zrownowazenia. Pulawy: Studia i Raporty IUNG-PIB, vol. 40(14), pp. 10-16.

14. Mickiewicz B, Mickiewicz A., Sobala M. (2013). Analiza przyczyn zmiany powierzchni uzytkow rolnych $w$ okresie miedzyspisowym (2002-2010). Optimum. Studia Ekonomiczne, No. 4, pp. 16-23.

15. Orlykovskyi M. and Wicki L. (2016). Polityka i programy wsparcia rolnictwa w warunkach stowarzyszenia $i$ czlonkowstwa Polski w Unii Europejskiej. Wnioski dla Ukrainy. Warszawa: Wydawnictwo SGGW, pp. 77-98.

16. Roman M., Nuszkiewicz K. (2013). Changes In Agricultural Production In Poland After Accession To The European Union. Problems of World Agriculture, vol. 13, No. 4, pp. 157-161.

17. Sobczyk M. (2013). Ekonometria. Warszawa: Wydawnictwo C.H. Beck, pp. 33-67

18. Subsidies Versus Economics, Finances And Income Of Farms (2016). J. Goral (ed.). Warszawa: IERiGZPIB pp. 30-36, 49-50.

19. Wigier M. (2014). The Competitiveness Of Polish Agriculture After Accession To The EU. Economics of Agriculture vol. 1/2014, pp. 91-92 